\title{
DEVELOPMENT TRENDS OF MILK PRODUCTION MECHANISATION IN LATVIA
}

\author{
Juris Priekulis, Armins Laurs \\ Latvia University of Life Sciences and Technologies, Latvia \\ juris.priekulis@1lu.lv, armins.laurs@promedia.lv
}

\begin{abstract}
The article presents research in the development of milk production mechanisation in Latvia from 2000 to 2018. It has been found that in this period of time the size of small cow herds, where there are up to five cows, has been essentially reduced, but the number of cows in herds with 50 and more animals has been increased. In barns with up to five cows, mainly water supply and milking have been mechanised. Therefore, the labour intensity of people working in milk production reaches in average 850 man-hours calculating per cow per year. In turn, in herds with 50 to 200 cows, modern technologies are used and all kinds of work are mechanised. Therefore, the average labour intensity has been reduced to 141 man-hours calculating per cow per year, but in herds with 200 and more cows - to 61 man-hours calculating per cow per year. While in the national scale the average weighted labour intensity of people working in milk production from 2000 to 2018 has been reduced by $53 \%$ reaching 302 man-hours per cow per year. In Latvia also milking robotics is developing that at present is implemented on $4.74 \%$ level.
\end{abstract}

Keywords: cows, mechanisation, labour intensity.

\section{Introduction}

In all developed countries within the recent twenty five years there have been essential changes in milk farming. It is related to the transition from tied handling of cows to loose handling arranging special recreation boxes for animals. This, in turn, causes changes in farm manure removal technologies, as limited usage of litter results in production of liquid farm manure. Also labour consuming technological processes are automated and robotised, what reduces the labour intensity of workers. The changes influence also the system of information gathering and analysing, as it is done electronically using the herd management systems. Besides, animal concentration occurs and measurements for improvement of cow productivity are introduced. Nevertheless, the development of these processes is not equal in all countries. It is due to different climatic conditions, labour force and energy costs, and other factors. This is well reflected in the results of the research performed in different countries [1-8].

Similar changes can be observed also in Latvia, as milk farming is one of the leading agricultural branches in the country. For instance, in 2018 the income from milk production in the country was $24 \%$ of the total income from agriculture [9]. The development of this branch is promoted by the favourable climatic conditions and long experience in milk production in Latvia. Much has been achieved also in selection of cows, ensuring increase of the average milk yield on the national level up to $7000 \mathrm{~kg}$ per cow per year [9; 10], but in approximately 50 farms it exceeds even $10000 \mathrm{~kg}$ per cow per year [10]. In many farms there are milking, feeding and feeding table cleaning robots operating.

Still, at present in Latvia clear information on the changes of the size of the herds and implementation of the new technologies is not available. Therefore, the aim of the present article is to summarize the results of the research in this field by the authors of the article, presenting information also on implementation of farm modernisation depending on the size of the cow herd.

\section{Materials and methods}

After regaining of independence, in Latvia in 1990 there was a crisis situation in milk farming as milk and milk processing products were not exported to Russia any more. For this reason milk production in Latvia during five years (till 1995) decreased almost two times - from 1871 thousand tons of milk to 948 tons of milk [1]. After that, a stabilization process started in agriculture, during which many farms of different sizes with different sizes of cow herds were created. Therefore, the research described in the present article covers the period of time from 2000 to 2018 . For this reason statistical data were summarized on the number of cows in Latvia, average milk yield and also the proportion of cows in herds depending on the size of the herd. For the research the herds were divided in four groups: up to 5 cows, from 6 to 49 cows, from 50 to 200 cows and more than 200 cows $[1 ; 2]$. It is due to the different management possibilities of the corresponding herds, like the kind of handling the animals, solution of mechanisation of work and the number of people engaged in animal farming. 
Using the information gathered by the authors of the article, as well as the reports of the student practice, the data on the applied milk production technologies and the corresponding machinery, as well as the number of people working in the farms depending on the size of the herd in more than 100 milk farms were obtained.

Having this information, it was possible to state the corresponding solution of mechanisation and machinery for every farm and the groups of cows, as well as to calculate the labour intensity of the workers and the degree of cow milking robotisation. For the calculations the following formulas were used [5].

For calculation of the specific labour intensity of people engaged in animal farming

$$
D_{c}=\frac{365 \cdot Z_{c} \cdot t_{d}}{Z_{g}},
$$

where $D_{c}$ - specific labour intensity of people engaged in animal farming, man-h per cow per year;

$Z_{c}$ - number of people working in the corresponding farm;

$t_{d}$ - average working hours of people per day working in the corresponding farm, in the calculations it is assumed $8 \mathrm{~h}$;

$Z_{g}$ - number of cows in the corresponding farm.

For calculation of the weighted labour intensity of the workers in the n-th year

$$
D_{c v n}=\frac{\sum D_{c x n} \cdot \lambda_{\% n}}{100}
$$

where $D_{c v n}$ - weighted labour intensity of the workers in milk farming in the $n$-th year, man-h per cow per year;

$D_{c x n}$ - average labour intensity of the workers in group $x$ in the $n$-th year, man-h per cow per year;

$\lambda \%$ - proportion of cows in group $x$ in the $n$-th year.

For calculation of the degree of cow milking robotisation for the $n$-th year

$$
\theta_{s l}=\frac{Z_{g x r}}{Z_{g x}} \cdot 100=\frac{100 \cdot n_{r x} \cdot Z_{g r}}{\lambda_{\% n} \cdot \sum Z_{g}} \cdot 100,
$$

where $\theta_{s l}-$ milking robotisation degree in $\mathrm{x}$-size group for the $n$-th year, $\%$;

$Z_{g x r}$ - number of cows in the $n$-th year in the herd of $x$-size group with robotic milking;

$Z_{g x}$ - total number of cows in $x$-size group of the herd in the $n$-th year;

$n_{r x}$ - number of robotised milking places in the $n$-th year in the corresponding size group of the herd;

$z_{g r}$ - average number of cows that can be milked by one robot (with one milking place). In thecalculations it is assumed that $z_{g r}$ is approximately 65 cows $[4 ; 5 ; 7]$;

$\sum Z_{g}$ - total number of cows in the country in the $n$-th year $[9 ; 10]$.

The characteristic indicators for every size group of the herd were calculated using the Excel data analysis software DescriptiveStatistics.

\section{Results and discussion}

According to the statistical data [9; 10], it can be stated that the number of cows in Latvia in the period of time from 2000 to 2018 has decreased from 204 thousand to 144 thousand cows or approximately by $33 \%$. In turn, the obtained milk yield has increased from 823 to 983 thousand tons (by $16.6 \%$ ). It is due to the increase of the average milk yield from $4025 \mathrm{~kg}$ to $6614 \mathrm{~kg}$ per cow per year, i.e. increasing by $64.3 \%$.

Also the size of the cow herd has changed essentially within the period of the time covered in the research. If in 2000 in Latvia $65 \%$ of the cows were in small size herds with up to 5 milk cows, then in 2018 in the herds of this size there were only $13 \%$ of the total number of cows. At the same time the number of cows has increased in the herds with 6 to 49 animals. Though, as it can be seen from the 
data given in Figure 1, this increase (from $20 \%$ to $38 \%$ ) has been observed only from 2000 to 2010, but after that it has stabilised and since 2014 it has even started to decrease. In turn, the herds with 50 to 200 cows, as well as the herds with more than 200 cows have increased approximately 2.5 times within these years reaching approximately $26 \%$ level in 2018.

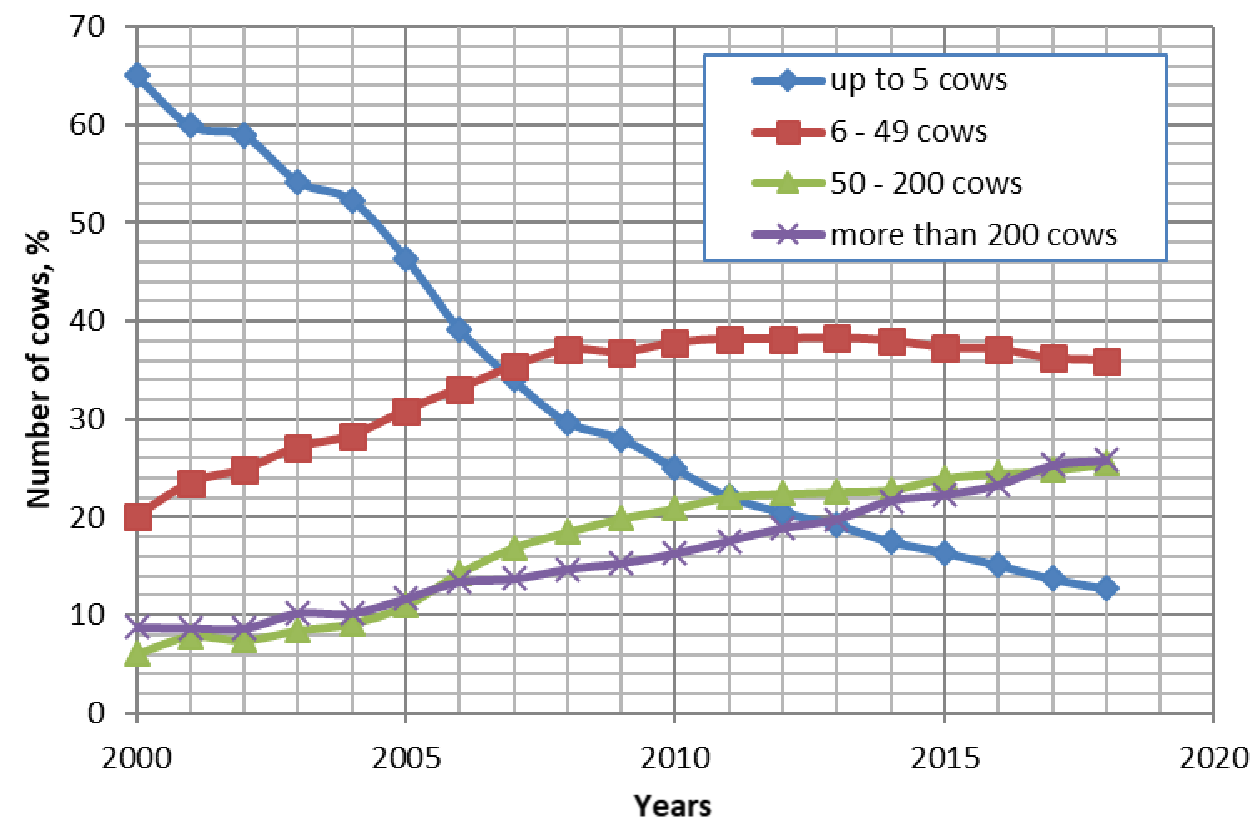

Fig. 1.Variations of cow herd size in Latvia from 2000 to 2018

Information on the kind of handling cows, solutions of mechanisation of work and the labour intensity of people engaged in rearing cows is summarized in Table 1.

Table 1

Characteristics of herds in 2018 depending on their size

\begin{tabular}{|c|c|c|c|c|}
\hline Size of the herd & Up to 5 cows & $\mathbf{6 - 4 9}$ cows & $\mathbf{5 0 - 2 0 0}$ cows & $\begin{array}{c}\text { More than } \\
\mathbf{2 0 0} \text { cows }\end{array}$ \\
\hline Kind of handling & tied & $\begin{array}{c}87 \% \text { cases }- \text { tied, } \\
13 \%-\text { loose }\end{array}$ & $\begin{array}{c}50 \% \text { cases }- \text { tied, } \\
50 \%-\text { loose }\end{array}$ & loose \\
\hline $\begin{array}{c}\text { Mechanisation of } \\
\text { work (including } \\
\text { possible } \\
\text { robotisation), } \%\end{array}$ & $\begin{array}{c}\text { Water supply }-98 \\
\text { Milking }-98\end{array}$ & $\begin{array}{c}\text { Water supply }-100 \\
\text { Milking }-100 \\
\text { Feeding }-8 \\
\text { Farm manure } \\
\text { removal }-59\end{array}$ & $\begin{array}{c}\text { Water supply }-100 \\
\text { Milking }-100 \\
\text { Feeding }-95 \\
\text { Farm manure } \\
\text { removal }-100\end{array}$ & $\begin{array}{c}\text { All basic work } \\
\text { at } 100 \% \text { level }\end{array}$ \\
\hline $\begin{array}{c}\text { Labour intensity } \\
\text { of workers, man-h } \\
\text { per cow per year* }\end{array}$ & $850 \pm 105$ & $395 \pm 46$ & $141 \pm 14$ & $61 \pm 7$ \\
\hline $\begin{array}{c}\text { Milking } \\
\text { robotisation, } \%\end{array}$ & - & - & 15.8 & 2.8 \\
\hline
\end{tabular}

*average relative standard error $\mathrm{S} \bar{x}$ does not exceed $6.0 \%$.

It can be concluded from the table that in small herds (up to 5 cows) only tied handling of cows is used and only water supply and milking are mechanised. Besides, for milking of cows mainly individual milking equipment is used. The labour intensity of people engaged in animal farming is comparatively large, reaching in average 850 man-hours per cow per year, what ensures regular work for one or two people.

If there are 6-49 cows in the herd, most often (in $87 \%$ of cases) tied handling of animals is used. Besides, not only water supply and milking are mechanised (using mobile appliances), but approximately in $60 \%$ of the farms manure is removed by scraper conveyors. In separate farms (in 
$8 \%$ of cases) also feeding of animals is mechanised using mobile aggregates. Though, in most cases cows are held in old barns. Therefore, wider implementation of mechanised feeding is hindered by the small barn door sizes and the width of the feeding passes that limit the usage of mobile machinery. The specific labour intensity reaches in average 395 man-hours per year calculating per one cow. Besides, all basic operations of work are ensured mainly by the family members of the owner of the farm or recruiting also several hired workers.

In the herds with 50 to 200 cows, transition from tied to loose handling of cows takes place. Therefore, approximately in already $50 \%$ of cases loose handling is used. Besides, all basic work operations are mechanised, but almost $16 \%$ of cows are milked with robotised equipment. In separate cases also other work operations are mechanised, for instance, feeding of animals and cleaning of the feeding tables. The average labour intensity reaches 141 man-hours calculating per cow per year. It is approximately 2.5 times less than in the previous case. Still, considering the increased number of cows in such farms, it is impossible to manage without hired workers. The only exception can be the farms, where milking and several other work operations are robotised.

In the herds with more than 200 cows only loose handling of cows is practiced and all technological processes are adapted to this kind of handling. Cows are most often milked in a separate parlour using the stall type equipment, but almost $3 \%$ of the total number of cows are milked with robotised equipment. The specific labour intensity has reduced in average to 61 man-hours calculating per cow per year. Mainly hired workers are recruited. The information of the labour intensity variations from 2000 to 2018 obtained in the research is shown in Figure 2.

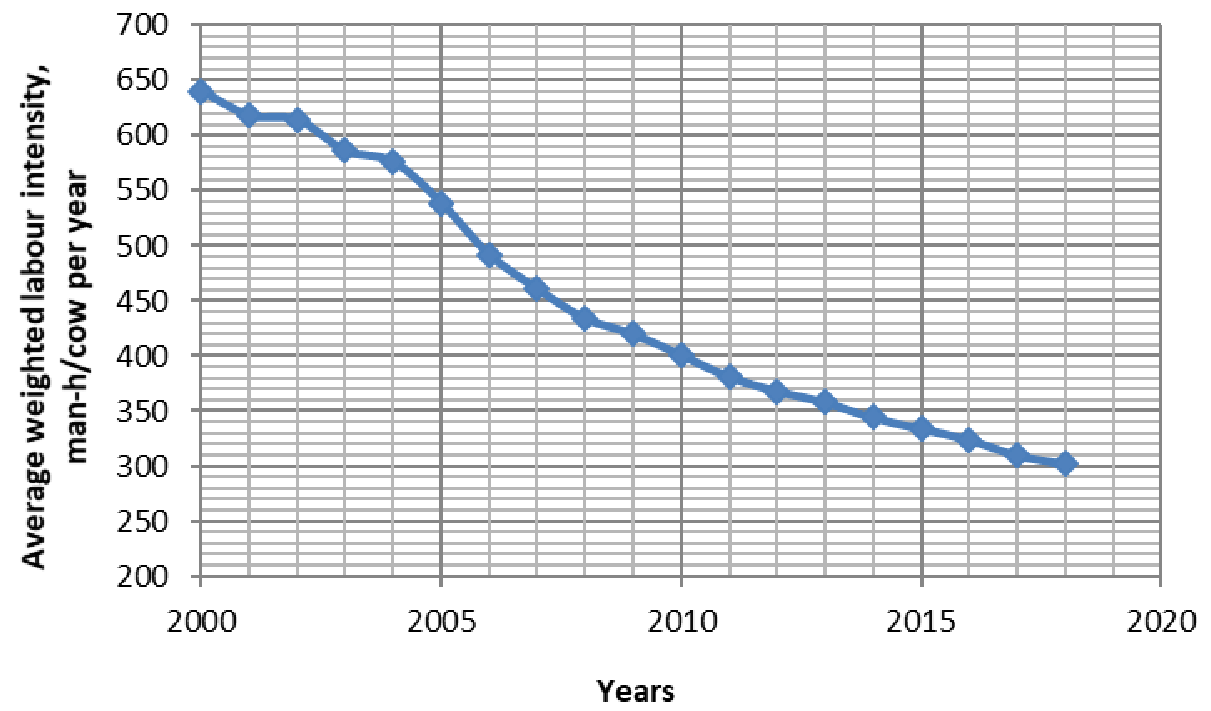

Fig. 2. Labour intensity variations of people engaged in milk farming from 2000 to 2018, man-h per cow per year

It can be concluded from the figure that enlargement of the herds and introduction of mechanisation of work have essentially reduced the labour intensity of people working in animal farming. If in 2000 it was 640 man-hours calculating per cow per year, then in 2018 - only 302 manhours. Consequently, the average decrease of the labour intensity is 18.8 man-hours per year. Besides, it can be prognosticated that variations of labour intensity in milk farming can continue also in the nearest future. It is related to the reduction of the number of small herds (up to 5 cows and from 5 to 49 cows) as well as to technical modernisation of operations of work, for instance, wider application of milking robots. It means that within the next ten years the number of people working in milk farming can reduce at least by $30 \%$.

The methods that we are using for calculation of labour intensity of people working in milk farming can be used also in other countries. For instance, according to the statistical data in Estonia [13], the previously used proportional distribution of milk cow herd sizes in 2018 had been respectively $10.1 \%, 9.5 \%, 52.9 \%$ and $27.5 \%$. Therefore, it can be calculated that the labour intensity 
of the workers in Estonia in 2018 had been by about $30 \%$ less than in Latvia, as there are not so large milk cow herds and it is not possible to apply modern machinery so widely for their tending.

\section{Conclusions}

1. In Latvia concentration of cow herds is taking place. If in 2000 approximately $65 \%$ of the total number of cows in the country were in herds up to 5 cows, then in 2018 this number of cows reduced to $12.7 \%$, but approximately a half of the total number of cows were in herds larger than 50 animals.

2. The size of the cow herd essentially influences the technology and mechanisation of milk production. In herds with up to 5 cows animals are handled tied and only water supply and milking are mechanised. Implementation of modern technologies and machinery starts mainly, if there are more than 50 cows in the herd. It influences also the labour intensity of people working in milk production. If there are up to 5 cows in the herd, the average labour intensity is 850 manhours calculating per cow per year, in herds with 6 to 49 cows - 396 man-hours, in herds with 50 to 200 cows - 141 man-hours, but in herds larger than 200 cows -61 man-hours calculating per cow per year.

3. Due to the changes in the sizes of the cow herds the average weighted labour intensity of people working in milk production from 2000 to 2018 has reduced in the country by $53 \%$ reaching 302 man-hours calculating per cow per year.

4. In Latvia in 2018 milking robotisation was implemented on $4.74 \%$ level, but mostly milking robots were used in herds from 50 to 200 cows, where $15.8 \%$ of cows of the total amount of animals were milked by milking robots.

\section{References}

[1] Parson D. J., Mottram T. T. F. An assessmenentt of herd management aspects of robotic milking on UK dairy farms. In: Proceedings of the international symposium "Robotic Milking", Netherland: Lelystadt (17.-19. August, 2000), pp. 212-220.

[2] Rinemann D.J., Smith D.J. Evaluation of automatic milking systems for the United States. In: Proceedings of the international symposium "Robotic Milking", Netherland: Lelystadt (17.-19. August, 2000), pp. 232-238.

[3] Vegricht J., Doležal O. Automatic milking system and theirchancesin the Czech Republic. In: Proceedings of the inernational symposium "Robotic Milking", Netherland: Lelystadt (17.-19. August, 2000), p. 239.

[4] Sedlmeyer F., Wendl G., Schön H. Automatic milking systems (AMS) inpracticaluse Situationin Bavaria. In: Proceedings of the inernational conference "Construction, Engineering and Environment in Livestock farming", Germany: Hohenheim (6.-7.March, 2001), pp. 422-425.

[5] Melkroboter Management./ Top agrar ratgeber. Landwirtschaftsverlag GmbH, Münster, 2012. S.112.

[6] Over R. Arbeitwirtschaft und Kosten automatischer Melksysteme. In: Milchpraxsis, No. 3, 2013, s. 20-23.

[7] Harm J., Wendl G. Analyse von Kapazitätsreserven bei automatischen Melksystemen. In: Landtechnik 64 (2009), No. 6, s. 432-435

[8] Arendzen I., Scheppingen A. T. J. Economical sensitivity of four main parameters defining the room for investment of automatic milking systems on dairy farms. In: Proceedings of the international symposium "Robotic Milking", Netherland: Lelystadt (17.-19. August, 2000), pp. 201-211.

[9] Agricultural Yearly Reports, 2000-2019. (Lauksaimniecības gada ziņojumi), 2000.-2019.g. [online][11.02.2020] Available at: https://www.zm.gov.lv/lauksaimnieciba/statiskaslapas/lauksaimniecibas-gada-zinojumi?nid = 531\#jump

[10]Latvian Agriculture. Central Statistics Bureau of the Republic of Latvia. (Latvijas lauksaimniecība. Latvijas Republikas centrālā statistikas pārvalde.) Avaitable at: htpp:scb.gov.lv

[11] Priekulis J.K., Aboltins A.J., Laurs A.P. Economic Evaluation of Equipment Modernisation and Improvement of Technologies in Milk Farming in Latvia. Scientific articles BIM. Volume 132. Moscow. 2000. - 237-241 p. (Приекулис Ю.К., Аболтиньш А.Я., Лаурс А.Р. Экономическая 
оценка модернизация оборудования и совершенствования технологии в молочном скотоводстве в Латвий. Научные труды ВИМ. Том 132. Москва. 2000. с. 237-241).

[12] Priekulis J., Laurs A. Economic evaluation of milking equipment. /Problems of intensification of animal production including environment protection and alternative energy production as well as biogas. Monograph under the scientific editorship of prof.W.Romaniuk. Falenty - Warsaw 2018. pp.141.-144.

[13]Estonian Livestock Performance Recording Ltd. [online][11.02.2020] Available at: https://www.epj.ee/ 